\title{
Knowledge Sharing Practices as a Basis of Product Innovation: A Case of Higher Education in Iraq
}

\author{
Sawasn Al-Husseini and Ibrahim Elbeltagi
}

\begin{abstract}
Knowledge is recognised the most significant resource for competitive advantage and the key to enhancing innovation. Knowledge sharing (KS) is considered to be a building block of efficient performance within higher education environments and to play a key role in enhancing the innovation of universities. The aim of this paper is to explore the effect of knowledge sharing on product innovation in Iraqi public higher education institutions. Structural equation modelling (SEM) with AMOS 20 was used, the results found that knowledge sharing play a pivotal role in enhancing product innovation within higher education environment.
\end{abstract}

Index Terms-Knowledge sharing, product innovation, higher education, Iraq.

\section{INTRODUCTION}

Higher education sector today are facing global challenges from a dynamic environment characterised by rapid technological change. Academic institutions need to develop their abilities and respond to these demands like business organisations [1]. As the world increasingly moves towards competition, knowledge and sharing it is recognised the most significant resource for competitive advantage [2] and the key to enhancing innovation. It increases the effectiveness of the organisation, and its creativity by converting the tacit knowledge embedded in individuals into explicit knowledge through interaction [3]. It is argued that through $\mathrm{KS}$, individuals can improve their capacity to solve unstructured and complicated problems, reduce their mistakes, and increase their learning [4].

Higher education in developing countries like Iraq is facing rapidly changing challenges that require innovation [5]. Educational markets are becoming increasingly global nowadays, and the ability of the education system in Iraq to reach a global market will depend on changes in the systems, methods, and curricula. Within higher education environments, KS is known to be a building block of efficient performance and to play a key role in enhancing the innovation of universities [6]. It is thought to be the foundation of learning and research at universities and a vital pillar of knowledge management (KM) that is critical to academic innovation.

Researchers have acknowledge the relationship between KS and innovation [7], [8], but few touch on knowledge processes (donating and collecting) and their impact on teaching staff's product innovation within developing

Manuscript received October 11, 2013; revised December 15, 2013.

Sawasn Al-husseini and Ibrahim Elbeltagi are with the University of Plymouth, School of Management, UK (e-mail: sawasn.al-husseini@plymouth.ac.uk,i.elbeltagi@plymouth.ac.uk). countries like Iraq. Innovation is important for organisations including learning institutions such as universities, thus, this research aims to explore the impact of knowledge sharing processes namely donating and collecting on product innovation using the context of public Iraqi higher education institutions (HEIs).

\section{KNOWLEDGE SHARING AND INNOVATION}

Today's organisations are increasingly focusing on innovation as a key factor in success and competitive advantage. Innovative organisations are able to adapt and respond to rapid an unstable environment and technological changes and survive in the present environment [9]. Innovation can be understood as developing, generating, adopting, and implementing new ideas, methods, programmes, and policies so as to achieve the goals of an organisation effectively. Chen et al. [10] noted that product innovation has the ability to improve production and distribution processes. It is one of the critical success factors for organisational growth and increased profits [11].

Rogers [12] asserted that educational institutions were a way to adopt and apply innovation. Educational quality is reliant on product being adaptive to the changing environment. Therefore, it is necessary to study this type of innovation within the higher education (HE) environment. This research defines innovation as "accepting, developing, and implementing new products such as courses, research projects, teaching materials, and curricula.

In the KM literature, past research reported different types for knowledge $(\mathrm{K})$, but the most commonly used are tacit and explicit knowledge. Tacit knowledge describes the personal, the subjective, and the intangible. It is embedded in the minds of people, is accumulated through learning, and experiences, and developed through conversations, workshops, job training, and social interaction. In contrast to tacit knowledge, explicit knowledge denotes knowledge that is articulated, objective, externalised and captured, and has a more tangible format [13].

$\mathrm{KM}$ involves the creating, sharing and using of knowledge [7]. It has been noted that, when considering the application of KM initiatives, it is important to create a culture of KS [14]. KS includes activities in which information, skills, insights are exchanged among organisational members [15].

It is defined as a two-dimensional process, with members of staff sharing and exchanging their tacit and explicit knowledge. Daily interaction creates new knowledge through the process of knowledge exchange, donation, and collection [16].

Access to knowledge may help organisational members to 
come up with new ways to solve problems and engage in further innovative activities. Innovation depends on employees' knowledge, skills, and experiences in value creation [17]. The knowledge-based view suggests that organisations need to exhibit knowledge creation but more importantly KS [18]. Since knowledge is embedded in individuals, it is necessary for it to be shared among organisational members so that they can establish new routines and mental processes that may help them to solve their problems [2]. When organisational members share their tacit knowledge and convert it into explicit knowledge through collecting and donating, collective learning is generated, which in turn improves the stock of knowledge available to the organisation. It is argued that organisations that promote a KS culture among organisational members are likely to generate new ideas that lead to product innovation [2], [19].

Previous studies have reported that KS is a basis of product innovation. For instance, Wei and Xie [20] found that KM could improve innovation performance within industrial companies in China. Similarly, Kamasak and Bulutlar [21] demonstrated that knowledge collecting had more effect on exploitative and explorative innovation inside and outside departments than did donating knowledge in the context of industrial companies in Turkey. Zaqout and Abbas [8] pointed out that explicit and tacit knowledge act as a bridge between trust, social networks, information and communication technologies, and performance within Malaysian public universities.

Although previous studies have established the relationship between $\mathrm{KS}$ and innovation, few touches on knowledge processes and their impact on the teaching staff's product innovation, there is a need for research understanding the practical difficulties of $\mathrm{KS}$ for product innovation [22] within developing countries and particularly the Iraqi environment, therefore, this research proposes the following:

1) H1: Knowledge donating will positively affect product innovation in Iraq's public HEIs.

2) H2: Knowledge collecting will positively affect product innovation in Iraq's public HEIs.

\section{METHOD}

The research used a quantitative approach to examine the effects of knowledge donating and collecting on product innovation. Eight items were developed from Hooff and Weenen [16] to measure KS reflecting the exchange of teaching-related knowledge, experience, and skills among teaching staff, and four items measured product innovation were drawn from [23] and [24]. These referred to the degree to which members of staff accepted, developed, and implemented new products such as courses, research projects, teaching materials and curricula. A self-administered questionnaire was developed, using five-point Likert scales ranging from 1-strongly disagree to 5-strongly agree. The questionnaire was translated into Arabic using the translation back-translation procedure. 400 questionnaires were sent to eight public colleges using the delivery and collection method, of which 240 were returned and usable for analysis.

\section{REsults}

SEM with AMOS 20 was used to test the causal relationship between knowledge donating and collecting, and product innovation. SEM consists of two steps: a measurement model to evaluate the convergent validity of the constructs, and a structural model to test and evaluate the causal relationships among factors. The three factors are evaluated through confirmatory factor analysis (CFA). The convergent validity was tested by investigating significant factor loadings of 0.5 or higher [25]. Additionally, the average variance extracted (AVE) measure was used, which should be 0.5 or higher [26]. Reliability was assessed separately for each dimension included in the model, based on the Cronbach's alphas and composite reliability (CR), each of which should exceed 0.7 [25]. The results shown in Table II indicate that the convergent validity and internal reliability were satisfactory. All factor loadings, and the CR and AVE were acceptable and significant.

TABLE I: VALIDITY AND RELIABILITY OF THE MODEL

\begin{tabular}{|c|c|c|c|c|c|}
\hline Factor & Code & Loading & $\alpha$ & AVE & $\mathrm{CR}$ \\
\hline \multirow{4}{*}{$\begin{array}{c}\text { Knowledge } \\
\text { donating }\end{array}$} & KD1 & 0.800 & \multirow[t]{4}{*}{0.81} & \multirow[t]{4}{*}{0.70} & \multirow[t]{4}{*}{0.82} \\
\hline & KD2 & 0.840 & & & \\
\hline & KD3 & 0.770 & & & \\
\hline & KD4 & 0.768 & & & \\
\hline \multirow{4}{*}{$\begin{array}{l}\text { Knowledge } \\
\text { collecting }\end{array}$} & KC5 & 0.775 & \multirow[t]{4}{*}{0.87} & \multirow[t]{4}{*}{0.73} & \multirow[t]{4}{*}{0.88} \\
\hline & KC6 & 0.890 & & & \\
\hline & KC7 & 0.850 & & & \\
\hline & $\mathrm{KC} 8$ & 0.840 & & & \\
\hline \multirow{4}{*}{$\begin{array}{c}\text { Product } \\
\text { Innovation }\end{array}$} & PI9 & 0.818 & \multirow[t]{4}{*}{0.83} & \multirow[t]{4}{*}{0.72} & \multirow[t]{4}{*}{0.83} \\
\hline & PI10 & 0.731 & & & \\
\hline & PI11 & 0.880 & & & \\
\hline & PI12 & 0.778 & & & \\
\hline
\end{tabular}

Note: $\mathrm{AVE}=$ average variance extracted, $\mathrm{CR}=$ composite reliability, $\alpha=$ Cronbach's alpha, $N=240$.

Discriminant validity was assessed using the criteria established by Fornell and Larcker [26]. According to them, the AVE should be greater than the squared correlations between two constructs. The constructs for all of the data were found to be empirically distinct and the discriminant validity was statistically confirmed. Table II displays the means and standard deviations. Additionally, it shows that the variances extracted from the constructs were greater than all of the squared correlations between items.

TABLE II: THE DISCRIPTIVE ANALYSIS AND DISCRIMINANT VALIDITY

\begin{tabular}{|l|c|c|c|c|c|}
\hline \multicolumn{1}{|c|}{ Factor } & Mean & SD & 1 & 2 & 3 \\
\hline 1-K donating & 3.41 & 0.88 & 0.70 & & \\
\hline 2-K collecting & 3.57 & 0.87 & 0.23 & 0.73 & \\
\hline 3-Product & 3.24 & 0.86 & 0.27 & 0.29 & 0.72 \\
\hline
\end{tabular}

Note: $\mathrm{SD}=$ standard deviation, $N=240$

TABLE III: THE FIT INDICES OF THE MODEL

\begin{tabular}{|c|c|c|c|}
\hline Fit indices & KS & $\begin{array}{c}\text { Product } \\
\text { Innovation }\end{array}$ & Target \\
\hline$\chi^{2} / d f$ & 1.342 & 1.715 & $\leq 2-5$ \\
\hline CFI & 0.973 & 0.963 & $\geq 0.90$ \\
\hline NFI & 0.954 & 0.950 & $\geq 0.90$ \\
\hline TLI & 0.975 & 0.968 & $\geq 0.90$ \\
\hline RMSEA & 0.042 & 0.035 & $<0.05-0.08$ \\
\hline
\end{tabular}

The research used also the fitness of fit indices for evaluating the measurement model as shown in Table III. 
This including $\chi^{2}, \chi^{2} / d f$, the goodness-of-fit index (GFI), and the root mean square error of approximation (RMSEA), and incremental fit measurement, which includes a normed fit index (NFI), and a comparative fit index (CFI) [25].

To test the structural model the results from SEM show that the goodness-of-fit indices indicate adequate levels of fit for the model (see Table IIII and Fig. 1). H1 is concerned with the effect of knowledge donating on product innovation. The path coefficients were confirmatory at level 0.644 and significance shown by $p<0.05$, indicating that $\mathrm{H} 1$ is supported.

$\mathrm{H} 2$ is concerned with the effect of knowledge collecting on product innovation. Table IV shows effective size of 0.687 , thus $\mathrm{H} 2$ is confirmed.

TABLE IV: THE STRUCTURAL ANALYSIS OF THE MODEL

\begin{tabular}{|c|c|c|c|}
\hline Hypothesis & Independent & dependent & Estimate \\
\hline $\mathrm{H} 1$ & $\begin{array}{c}\text { Knowledge } \\
\text { donating }\end{array}$ & Product & $0.644 * *$ \\
\hline $\mathrm{H} 2$ & $\begin{array}{l}\text { Knowledge } \\
\text { collecting }\end{array}$ & Product & $0.687^{*}$ \\
\hline $\mathrm{H} 1, \mathrm{H} 2$ & Knowledge sharing & $\begin{array}{c}\text { Product } \\
\text { innovation }\end{array}$ & $0.6399 * *$ \\
\hline Fit indices & \multicolumn{3}{|c|}{$\begin{array}{l}\chi^{2} / d f=1.262, \text { RMSEA }=0.032, \mathrm{NFI}=0.938, \mathrm{CFI}=0.957 \\
\text { TLI }=0.947\end{array}$} \\
\hline
\end{tabular}

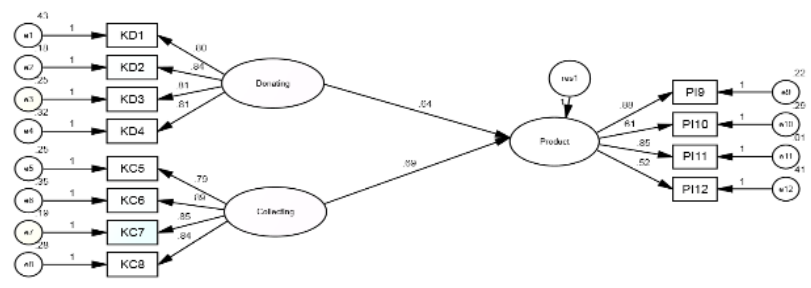

Fig. 1. Results of SEM

\section{DISCUSSION}

KS processes were found in this paper to be positively related to product innovation in Iraqi HE. Knowledge is a valuable resource of organisations [2], [13]. The role of knowledge and sharing it has emerged as an important area in the investigation of innovation in organisations. Product innovation is enhanced when organisational members exchange information, insights, skills, lessons learned, and experiences [17]. The knowledge-based view suggests that organisations need to generate as well as share knowledge [13], [27]. When knowledge is used, learning takes place which in turn leads to changes of behaviour and innovation [2], [28].

Supar [29] noted that the encouragement and practising of KS activities among teaching staff can enhance performance and create opportunities for innovation. The results of this paper demonstrate that the members of staff surveyed in Iraqi public HEIs are willing to donate and collect their skills, insights, experiences, expertise, information and notes both inside and outside of their own departments, which enables their universities to improve their product e.g. research and projects with other sectors, new courses, and curricula. The findings are congruent with Ferraresi et al. [30], who argued that KM processes, namely capturing, sharing, and application, can enhance innovation through the strategic orientation of the organisation.

\section{CONCLUSION}

This research aimed to examine the impact of knowledge sharing on product innovation. The results found that knowledge sharing is a basis of product innovation in Iraqi HE environment. This paper makes a theoretical contribution to the literature on KS and innovation, and provides support for the knowledge-based view theory and empirically strengthens the role KS plays in enhancing product innovation in Iraqi HEIs. These results give us a better understanding of how knowledge can lead to competitive advantage in HEIs. KS is known to transfer individual experiences, knowledge, skills, expertise, and information into explicit and organisational assets for better innovation. Managing knowledge and sharing it, as a strategic resource is one of the foundational weapons that enable universities to increase their competitive advantage and chances of survival. Therefore, the leaders in Iraqi universities need to expend effort and design strategies on promoting $\mathrm{KS}$ activities among their teaching staff such as sessions, conferences, workshops, etc. for better product innovation.

APPENDIX: QUESTIONNAIRE ITEMS

\begin{tabular}{|c|c|}
\hline Construct & Item \\
\hline \multirow[t]{4}{*}{$\begin{array}{l}\text { Knowledge } \\
\text { donating }\end{array}$} & $\begin{array}{l}\text { Knowledge sharing with colleagues is considered } \\
\text { normal thing in my department }\end{array}$ \\
\hline & $\begin{array}{l}\text { When they have learned something new, my } \\
\text { colleagues within my department tell me about it }\end{array}$ \\
\hline & $\begin{array}{l}\text { When they have learned something new, colleagues } \\
\text { outside of my department tell me about it. }\end{array}$ \\
\hline & $\begin{array}{l}\text { Knowledge sharing with colleagues is considered } \\
\text { normal thing outside of my department. }\end{array}$ \\
\hline \multirow[t]{4}{*}{$\begin{array}{l}\text { Knowledge } \\
\text { collecting }\end{array}$} & $\begin{array}{l}\text { I share any information I have with colleagues within } \\
\text { my department when they ask for it. }\end{array}$ \\
\hline & $\begin{array}{l}\text { I share my skills with colleagues within my } \\
\text { department when they ask me to. }\end{array}$ \\
\hline & $\begin{array}{l}\text { I share information I have with colleagues outside of } \\
\text { my department, when they ask me to. }\end{array}$ \\
\hline & $\begin{array}{l}\text { Colleagues outside of my department tell me what } \\
\text { they know when I ask them about it. }\end{array}$ \\
\hline \multirow[t]{4}{*}{$\begin{array}{l}\text { Product } \\
\text { innovation }\end{array}$} & $\begin{array}{l}\text { Our university is always delivering new courses for } \\
\text { members of staff. }\end{array}$ \\
\hline & $\begin{array}{l}\text { Our university constantly emphasises development } \\
\text { and doing research projects. }\end{array}$ \\
\hline & $\begin{array}{l}\text { Our university often develops teaching materials and } \\
\text { methodologies. }\end{array}$ \\
\hline & $\begin{array}{l}\text { Our university is developing new training } \\
\text { programmes for staff members. }\end{array}$ \\
\hline
\end{tabular}

\section{REFERENCES}

[1] S. Kim and B. Ju, "An analysis of faculty perceptions: Attitudes toward knowledge sharing and collaboration in an academic Institution," Library and Information Science, vol. 30, no. 4, pp. 282-290, 2008.

[2] G. V. Krongh, I. Nonaka, and L. Rechsteiner, "Leadership in organizational knowledge creation: A review and framework," Journal of Management Studies, vol. 49, no.1 pp. 240-277, 2012.

[3] A. Abell and N. Oxbrow, Competing with knowledge: The information professional in the knowledge management age, London, UK: Library Association Publishing, 2001.

[4] J. Saenz, N. Aramburu, and O. Rivera, "Knowledge sharing and innovation performance: A comparison between high-tech and low-tech companies," Journal of Intellectual Capital, vol. 10, no. 1, pp. 22-36, 2009.

[5] T. Herbst and P. Conradie, "Leadership effectiveness in Higher Education: Managerial self-perceptions versus perceptions of others," Journal of Industrial Psychology, vol. 37, no. 1, pp. 1-14, 2011. 
[6] V. Mathew, "Service delivery through knowledge management in higher education," Journal of Knowledge Management Practice, vol. 11, no. 3, pp. 1-14, 2010.

[7] T. Andreeva and A. Kianto, "Knowledge processes, knowledge-intensity and innovation: A moderated mediation analysis," Journal of Knowledge Management, vol. 15, no. 6, pp. 1016-1034, 2011.

[8] F. Zaqout and M. Abbas, "Towards a model for understanding the influence of the factors that stimulate university students' engagement and performance in knowledge sharing," Library Review, vol. 61, no. 5 , pp. 345-361, 2012.

[9] P. Trott, Innovation Management and New Product Development, 4th ed., London, UK: Prentic Hall, 2008.

[10] M. Chen, C. Lin, H.-E. Lin, and E. Mcdonough, "Does transformational leadership facilitate technological innovation? The moderating roles of innovative culture and incentive compensation," Asia Pacific Journal of Management, vol. 29, no. 2, pp. 239-264, 2012

[11] M. Schilling, Strategic Management of Technological Innovation, 3rd ed., New York: McGraw-Hill/Irwin, 2010.

[12] E. Rogers, Diffusion of Innovation, 4th ed., New York: The Free Press, 2010.

[13] I. Nonaka and R. Toyama, "The theory of the knowledge-creating firm: Subjectivity, objectivity and synthesis," Industrial and Corporate Change, vol. 14, no. 3, pp. 419-436, 2005.

[14] D. Hislop, Knowledge Management in Organisations, 3rd ed., UK: Oxfor University Press, 2013.

[15] T. Kim, G. Lee, S. Paek, and S. Lee, "Social capital, knowledge sharing and organizational performance: What structural relationship do they have in hotels?" International Journal of Contemporary Hospitality Management, vol. 25, no. 5, pp. 1-14, 2013.

[16] V. Hooff and F. Weenen, "Committed to share: commitment and CMC use as antecedents of knowledge sharing," Knowledge and Process Management, vol. 11, no. 1 pp. 13-24, 2004.

[17] Z. Wang and N. Wang, "Knowledge sharing, innovation and firm performance," Expert Systems with Applications, vol. 39, no. 10, pp. 8899-8908, 2012.

[18] M. Alavi and D. Leidner, "Review: knowledge management and knowledge management systems: conceptual foundations and research issues," MIS Quarterly, vol. 25, no. 1, pp. 107-136, 2001.

[19] S. Mehrabani and M. Shajari, "Knowledge management and innovation capacity," Journal of Management Research, vol. 4, no. 2, pp. 164-177, 2012.

[20] X. Wei and F. Xie, "Knowledge management processes and innovation An empirical analysis of firms in software cluster," International Journal Human Resources Development and Management, vol. 8, no $1-2$, pp. 25-24, 2008.

[21] R. Kamasak and F. Bulutlar, "Influence of knowledge sharing on innovation," European Business Review, vol. 22, no. 3, pp. 306-317, 2010.

[22] J. Xu, R. Houssin, C. Emmanuel, and M. Gardoni, "Macro process of knowledge management for continuous innovation," Journal of Knowledge Management, vol. 14, no. 4, pp. 573-591, 2010.

[23] S. Perri, "Innovation by nonprofit organizations: Policy and research issues," Nonprofit Management and Leadership, vol. 3, no. 4, pp.397-414, 1993.

[24] R. Daft, "Organizational innovation," Academy of Management Journal, vol. 21, no. 2, pp. 193-210, 1978.
[25] J. Hair, W. Black, B. Babin, and R. Anderson, Multivariate Data Analysis: A Global Perspective, 7th ed, US: Pearson Prentice Hall, 2010.

[26] C. Fornell and D. Larcker, "Evaluating structural equation models with unobservable variables and measurement error," Journal of Marketing Research, vol. 18, no. 1 pp. 39-50, 1981

[27] E. Cheng, "Knowledge strategies for enhancing school learning capacity," International Journal of Educational Management, vol. 26, no. 6 , pp. 577-592, 2012

[28] K. Ichijo and I. Nonaka, Knowledge Creation and Management New Challenges for Managers, New York: Oxford University Press, 2007.

[29] N. Supar, "Factors affecting knowledge sharing among academic staff in selectetted Malaysian higher educational institutions and the effecton performance," Ph.D. thesis submitted to the University of Putra Malayis,School of Management, 2006.

[30] A. Ferraresi, C. Quandt, S. Santos, and J. Frega, "Knowledge management and strategic orientation: Leveraging innovativeness and performance," Journal of Knowledge Management, vol. 16, no. 5 pp. 688-701, 2012

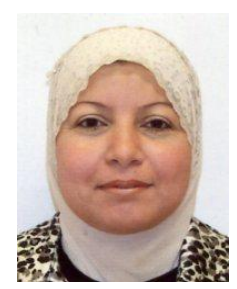

Sawasn Al-husseini is currently a Ph.D. candidate at Plymouth University, School of Management in the UK and a lecturer at Foundation of Technical Education, Institute of Administration Rusafa, Baghdad, Iraq, her Ph.D. in management information system (MIS). Sawasn did her B.Sc in Business Administration at Baghdad University and M.Sc from Al-Mustansiriya University, Iraq. She has published five journal papers in innovation, leadership style, organizational loyalty, knowledge management, and knowledge sharing in Iraq. Recently she published four papers on knowledge sharing in proceedings of the $10^{\text {th }}$ European conference on E-learning in the UK. Leadership and knowledge sharing in proceedings of the $4^{\text {th }}$ and $5^{\text {th }}$ European conference in intellectual capital in Finland and Spain respectively and in knowledge sharing and educational innovation in $10^{\text {th }}$ International Conference on Intellectual Capital, Knowledge Management \& Organisational Learning, in USA.

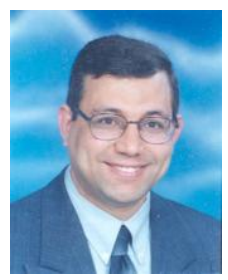

Ibrahim Elbeltagi is a lecturer in information and knowledge management at the School of Management, University of Plymouth, UK. Business Information Management Systems Programme Manager, he is responsible for modules in World of Business, Information and Decision Making, Electronic Society, Innovation and Project Management, Business Project and Research Methods and Director of Studies of the PhDs. Ibrahim did his B.Sc. and M.Sc in Marketing at Mansoura University, Egypt. The Ph.D. in Management Information Systems from Huddersfield University Business School, UK His publications are related to electronic commerce, E- government, adoption of ICT, information systems in developing countries, social networking, and knowledge management. He has more than 30 journal and conferences papers published in national and international journals and conferences. 